AperTO - Archivio Istituzionale Open Access dell'Università di Torino

\title{
Supranational creditors: A threat to the equal status of bondholders?
}

\section{This is the author's manuscript}

Original Citation:

\section{Availability:}

This version is available http://hdl.handle.net/2318/1520773

since 2021-03-08T11:23:05Z

Published version:

DOI:10.1093/cmlj/kmv017

Terms of use:

Open Access

Anyone can freely access the full text of works made available as "Open Access". Works made available under a Creative Commons license can be used according to the terms and conditions of said license. Use of all other works requires consent of the right holder (author or publisher) if not exempted from copyright protection by the applicable law. 
This is the author's final version of the contribution published as:

Viterbo, Annamaria. Supranational Creditors: A Threat to the Equal Status of Bondholders?. CAPITAL MARKETS LAW JOURNAL. 10 (2) pp: 193-211.

When citing, please refer to the published version.

Link to this full text:

http://hdl.handle.net/2318/1520773 


\section{Supranational Creditors: A Threat to the Equal}

\section{Status of Bondholders?}

Annamaria Viterbo

University of Turin, Italy

\section{ABSTRACT}

Sovereign bonds are actively traded in secondary markets and held by a broad community of creditors. The current profile of sovereign bondholders includes retail and institutional investors (banks, investment funds, pension funds, and insurance companies), also encompassing sovereign wealth funds, central banks, the IMF and similar organizations, as well as institutions like the ECB and the EIB. Bondholders have become increasingly diverse, numerous, anonymous and difficult to coordinate. To further complicate a common course of action, they might have conflicting interests, different drives and bargaining power, as well as significant information asymmetries.

The fragmentation of the bondholders' profile poses a host of complex issues to the development of a dedicated workout mechanism for the restructuring of sovereign bond debt. In particular, the challenges raised by 'supranational creditors' are yet to be carefully addressed. This term is used to describe international organizations (like the IMF and the IBRD) and supranational institutions (like the ECB) when they purchase 
sovereign bonds on the secondary market. These atypical sovereign bond investors are halfway between private retail investors and multilaterals providing financial assistance and they might pursue objectives other than mere profit.

The paper addresses the question whether, in a debt restructuring, supranational creditors should be treated equally to other bondholders or should be given priority. 


\section{Recent developments in the profile of bond investors: the issue of supranational bondholders}

Sovereign debt, either external or domestic ${ }^{1}$, is the debt issued or guaranteed by the central government of a State. ${ }^{2}$

States can borrow from a variety of sources. They can receive loans from international financial institutions (the International Monetary Fund, the World Bank and regional development banks), foreign governments and commercial banks (either individually or as part of a syndicate), or they can issue sovereign bonds on the international capital markets.

In the 19 th century and in the early years of the 20th century, most sovereign debt was in the form of bonds or loans disbursed by private banks (which granted mainly

\footnotetext{
${ }^{1}$ While a State's domestic debt is usually governed by its national law, subject to the exclusive jurisdiction of national courts, denominated in domestic currency and predominantly held by residents, the external debt is traditionally governed by a foreign law, subject to the jurisdiction of a foreign court and denominated in foreign currency.

${ }^{2}$ Recently, also the issue of the so-called 'quasi-sovereign debt' has been raised, which refers to the
} debt incurred by subnational political entities (provinces, municipalities and the like), and by State-owned enterprises. While State-owned enterprises are usually able to borrow externally even when the government does not guarantee its repayment, in some cases the administrative regions of sovereign States are prohibited by law to do so (for example, in the United Kingdom, but not in the United States). The global financial crisis highlighted the problems related to the debt owned by public enterprises, which in some cases was restructured on the same basis as sovereign debt, while in others was dealt with through the relevant domestic bankruptcy regime. See U Das, M Papaioannou, C Trebesch, 'Sovereign Debt Restructurings 1950-2010: Literature Survey, Data, and Stylized Facts' (2012) IMF Working Paper, WP/12/203, 56 ff. and A Gelpern, 'Bankruptcy, Backwards: The Problem of Quasi-Sovereign Debt' (2012) Yale Law Journal 121, 888-942. 
short-term trade financing or interbank credit lines). To deal with sovereign defaults, bondholders' committees ${ }^{3}$ were established and, occasionally, western powers even engaged in gunboat diplomacy to recover debts owed to their nationals.

After World War II, government-to-government loans became the preeminent form of borrowing and sovereign debt restructurings were dealt with by the Paris Club.

It was only in the 1970 s that States started to borrow from international commercial banks through long-term syndicated credit agreements. ${ }^{4}$ During the 1980 s, however, the majority of emerging countries defaulted on their bank loans, which had to be restructured by small creditor banks' committees collectively referred to as the London Club.

During the 1990s, bank lending to emerging economies declined as compared to sovereign bond financing and nowadays the external debt of sovereigns is mainly held

\footnotetext{
${ }^{3}$ In 1868 , in the UK, a consortium of loan houses and brokers created the Corporation of Foreign Bondholders. In the United States, the Foreign Bondholders Protective Council was established in 1933 under the Roosevelt administration to protect the interests of holders of foreign bonds and to negotiate with governments that defaulted on their debts. See P Mauro and Y Yafeh, 'The Corporation of Foreign Bondholders' (2003) IMF Working Paper, WP/03/107; MR Adamson, 'The Failure of the Foreign Bondholders Protective Council Experiment, 1934-1940’ (2002) 76 The Business History Review 479.

${ }^{4}$ During the 1970 s, bank lending to emerging market countries usually took the form of a syndicated loan, a club loan or a single-bank loan. Under a syndicated credit agreement, the borrowing country selects one or several commercial banks to act as arranger or co-arrangers against the payment of a fee.
} The arranger agrees to provide a share of the loan, prepares the terms of the syndicated credit agreement and sells portions of the loan to other participants. To facilitate the process of administering the loan on a daily basis, one bank from the syndicate is appointed as agent. Principal and interest payments are made by the borrower to the agent, which is responsible for their transfer to each syndicated member according to its share of the loan. 
in the form of bonds. Sovereign bonds are actively traded in secondary markets and held by a broad community of investors. The current profile of bondholders includes many categories of creditors, both domestic and foreign, which range from retail to institutional investors (banks, investment funds, hedge funds, pension funds, and insurance companies), also encompassing sovereign wealth funds, central banks, the IMF and similar international organizations, as well as institutions like the European Central Bank (ECB) and the European Investment Bank (EIB). Bond investors, however, are usually not represented in bondholders' committees or in the Paris and London Clubs, and restructurings take the form of sovereign bond exchanges.

It is clear from the above that, over the past sixty years, the features of sovereign debt restructurings have been shaped by the type of creditors and by the nature of the debt. Debt restructuring vehicles therefore change according to the category of creditors involved: (a) official bilateral debt is renegotiated under the Paris Club umbrella; (b) commercial bank debt is restructured through the so-called London Club process or Bank Advisory Committees; and (c) bond debt is restructured via exchange offers. However, while the Paris and the London Clubs developed as the preferred for a for the restructuring of debts owed by a State to homogeneous groups of creditors, the creditor structure of sovereign bonds is rather heterogeneous and a dedicate vehicle for restructuring is still to be devised.

The current profile of sovereign bondholders consists in fact of a group of investors very diversified and complex, ranging from individuals to commercial banks and including institutional investors as well as public sector entities. Bondholders have become increasingly diverse, numerous, anonymous and difficult to coordinate. To further complicate a common course of action, they might have conflicting interests, 
different incentives and bargaining power, as well as significant information asymmetries.

The challenges posed by the fragmentation of bondholders are particularly pronounced when it comes to supranational creditors. This term is here used to describe international organizations (the IMF and the IBRD) and supranational institutions (like the ECB and the EIB) when they purchase sovereign bonds on the secondary market.

The purpose of this research is to analyse the issues posed by the fragmentation of the bondholders' profile and in particular by the position of supranational creditors. In paragraph 2, a description is provided of the ways in which the principles of 'equality of treatment' and 'comparability of treatment' are applied in sovereign debt restructurings. Paragraph 3 and 4 focus on the preferred creditor status of the IMF, WB and MDBs: when providing financial assistance, their preferred creditor status has rarely been challenged; the question is whether the same should apply when these international organizations act as investors in the capital markets. Paragraph 5 deals with the factual priority the ECB, the Eurosystem national central banks (NCBs) and the EIB enjoyed during the Greek debt restructuring. Paragraph 6 examines whether, for the operation of the pari passu clause, supranational bondholders should be assimilated to private investors. Paragraph 7 concludes discussing the enfranchisement of supranational creditors under collective action clauses. 


\section{Equality and comparability of treatment in sovereign debt restructurings}

Unlike what happens in corporate bankruptcy, the priority ranking of creditors in sovereign insolvency is usually determined by negotiations, the chronological sequence of payments and market practice, which leaves out, for example, trade debt and shortterm interbank debt.

For what concerns the equality of treatment, the principle only applies within each class of creditors, which are: a) Paris Club members, b) banks negotiating through the process of the so-called London Club or a Bank Advisory Committee (BAC) and c) bondholders.

a) Non-discrimination among Paris Club members results from the Agreed Minutes that, at the end of the negotiations, are signed by the creditors' representatives, by the minister representing the debtor country and by the Chairman of the Club.

The Minutes amount to a gentlemen agreement, which each government is expected to honour in good faith, but per se are not legally binding. ${ }^{5}$ The Agreed Minutes, in fact, "are signed 'ad referendum' by the heads of the participating delegations, who thereby agree to 'recommend to their Governments... that they provide relief... on the following terms" ". 6 To give legal effect to what has been established during the

\footnotetext{
${ }^{5}$ The Agreed Minutes are signed by the parties involved, but they are not ratified afterwards. This shields the common agreement reached within the Paris Club from being the object of debate in national parliaments. According to some Authors, the Agreed Minutes can be considered treaties concluded by using the simplified procedure. See C Holmgren, La renégociation multilatérale des dettes: le Club de Paris au regard du droit international (1998) 217-226.

${ }^{6}$ See L Rieffel, Restructuring Sovereign Debt: The Case for Ad Hoc Machinery (2003) 91.
} 
negotiations, the terms formalized in the Minutes have to be transposed in bilateral agreements.

In parallel, a pullback clause ensures that if the debtor agrees better terms with its non-Paris Club bilateral creditors, the participating countries will declare the provisions set forth in the Agreed Minutes null and void.

b) The equality of treatment is also granted to commercial banks participating in a BAC process. At the end of the process, the BAC and the debtor sign the term sheet also called heads of terms or agreement in principle - which is submitted to all the members of the syndicate for approval.$^{7}$ For the agreement to become valid, unanimity is usually required, or acceptance by banks holding at least 95 per cent of the outstanding debt.

Usually a sharing clause is found in sovereign restructuring agreements for commercial bank debt, to prevent the debtor to give preference to any particular creditor. Pursuant to the clause, if a bank receives a greater payment from the obligor, it has to transfer the excess to the agent bank, which will redistribute the sum pro rata to each bank in the syndicate.

In addition, a most favoured debt clause provides that, if another foreign currency debt falling due on the same date is paid sooner or offered better terms, then the borrower must extend the same treatment to the rescheduled debt. ${ }^{8}$ The clause is conceived to encourage all eligible creditors to participate to the rescheduling. However, certain categories of debt are excluded from the scope of the clause, such as trade debt

\footnotetext{
${ }^{7}$ Usually, each material element of a restructuring package has to be agreed upon by the members of the BAC. On this point see LC Buchheit, 'Use of Creditor Committees in Sovereign Debt Workouts' (2009) 10 (3) Business Law International, 208.

${ }^{8}$ See PR Wood, Principles of International Insolvency (2nd edn, 2007), par. 25-060.
} 
and sovereign bonds; furthermore, in order to preserve their priority, the debt owed to the IMF and other international organizations is exempted.

Often, a negative pledge clause prohibits the debtor State from creating or allowing security interests over its assets. The purpose of the clause is to prevent the subordination of unsecured creditors, especially when, being in distress, the borrower can only raise funds by selling securities.

c) In the case of sovereign bonds, the equality of creditors is guaranteed by the operation of the pari passu clause $^{9}$ and other contractual provisions like the negative pledge and the most favoured creditor clause. ${ }^{10}$

The pari passu is a boilerplate provision in public or private international unsecured debt obligations. In its more common form, the clause reads: "The bonds are unsecured obligations of the issuer and rank at least pari passu, without any preference amongst themselves, with all other outstanding, unsecured and unsubordinated obligations of the issuer, present and future". 11

\footnotetext{
${ }^{9}$ On the pari passu clause see in particular: LC Buchheit, JS Pam, 'The Pari Passu Clause in Sovereign Debt Instruments’ (2004) 53 Emory Law Journal 869; R Olivares-Caminal, ‘To Rank Pari Passu or not to Rank Pari Passu: that is the Question in Sovereign Bonds' (2009) 15 (4) Law \& Business Review of the Americas 745-778; M Weidemaier, R Scott, M Gulati, 'Origin Myths, Contracts, and the Hunt for Pari Passu' (2013) 38 Law \& Soc. Inquiry 72.

${ }^{10}$ These clauses are similar to the ones found in rescheduling agreements for commercial banks debt. For instance, a 'rights upon future offers clause' (RUFO) is found together with the 'most favored creditor clause' (MFCC) in the restructured bond contracts of Argentina.

${ }^{11}$ PR Wood, International Loans, Bonds, Guarantees, Legal Opinions (2nd edn, 2007) par. 12-010 ff.
} 
The clause establishes both equality of bonds among themselves (the so-called internal element) and that the bonds are equal with all other unsecured or unsubordinated indebtedness of the issuer (the so-called external element). ${ }^{12}$

There are, however, two different interpretations of the pari passu. According to the mainstream approach, the clause only provides for the equality of legal ranking: bondholders are protected from legal subordination. In other words, a breach of the clause only arises if the debtor subordinates the protected debt through mandatory measures which would change the legal ranking.

Quite differently, according to a more recent interpretation, the clause would assert equal payment rights and consequently provide for rateable payments on a nondiscriminatory basis: when the debtor is unable to pay all its obligations, they will be paid on a pro-rata basis. As a result, creditors who had accepted an exchange offer cannot even be paid interests unless the same percentage of payment is made on both principal and interest due to the other pari passu creditors (in other words, unless holdouts receive the same fraction of their total credit accrued at a given date).

This interpretation was applied in a lawsuit raised against Argentina by NML Capital before US courts. ${ }^{13}$ The rulings provoked an earthquake on international finance and it

${ }^{12}$ R Olivares-Caminal, 'The Pari Passu Clause in Sovereign Debt Instruments: Developments in Recent Litigation', BIS Papers No. 72, July 2013, 123.

${ }^{13}$ This interpretation of the pari passu clause was adopted by Judge Thomas Griesa in the case $N M L$ Capital, Ltd. v. Republic of Argentina, No. 08 Civ. 6978 (TPG) (S.D.N.Y. Feb. 23, 2012): pursuant to the injunction order, Argentina has to make a 'rateable payment' to NML Capital (a so-called vulture fund) whenever it pays the holders of the restructured debt. 
was observed that they might discourage participation in future debt exchange offers, distort incentives and make sovereign debt restructurings less predictable and orderly. ${ }^{14}$

The injunction was affirmed in October 2012 by a unanimous panel of the US Court of Appeals, Second Circuit: NML Capital, Ltd. v. Republic of Argentina, 699 F.3d 246 (2d Cir. 2012) [2012 BL 283459] Docket 12-105(L), 26 October 2012.

Later on, in November 2012, the District Court issued amended injunctions with the clarifications requested by the Second Circuit: NML Capital, Ltd. v. Republic of Argentina, No. 08 Civ. 6978 (TPG), 2012 WL 5895786 (S.D.N.Y. Nov. 21, 2012).

In August 2013, the US Court of Appeals, Second Circuit affirmed the amended order: NML Capital Ltd. v. Republic of Argentina, 727 F.3d 230 (2d Cir. 2013), 23 August 2013. Par. 239 reads: 'In its opinion, the district court first explained that its 'rateable payment' requirement meant that whenever Argentina pays a percentage of what is due on the Exchange Bonds, it must pay plaintiffs the same percentage of what is then due on the FAA Bonds. Under the express terms of the FAA, as negotiated and agreed to by Argentina, the amount currently due on the FAA Bonds, as a consequence of its default, is the outstanding principal and accrued interest. [...] Thus, as the district court explained, if Argentina pays Exchange Bondholders $100 \%$ of what has come due on their bonds at a given time, it must also pay plaintiffs $100 \%$ of the roughly $\$ 1.33$ billion of principal and accrued interest that they are currently due.'

On 16 June 2014 the US Supreme Court rejected Argentina's appeal for a reversal of the lower courts’ rulings: Republic of Argentina v. NML Capital Ltd., US Supreme Court, No. 12-842, 2014 BL 165390 (16 June 2014).

${ }^{14}$ See Brief for the United States of America as amicus curiae in support of the Republic of Argentina's petition for panel rehearing and rehearing en banc (28 December 2012) filed before the United States Court of Appeals for the Second Circuit (New York) in the case NML vs. Republic of Argentina, case 12-105. Brief for the Republic of France as amicus curiae in support of the Republic of Argentina's petition for a writ of certiorari (26 July 2013) filed before the Supreme Court of the United States in the case Republic of Argentina v. NML (Docket Number 12-1494). Brief for the Republic of France as amicus curiae in support of the Republic of Argentina's petition for a writ of certiorari (24 March 2014) filed before the Supreme Court of the United States in the case Republic of Argentina v. 
To clarify the meaning of the clause, in August 2014 the International Capital Market Association (ICMA) published a new standard pari passu provision, ${ }^{15}$ revised in the light of NML, which received the endorsement of the IMF. ${ }^{16}$ The new boilerplate provision was drafted to ensure only equal ranking (i.e. the sovereign is prohibited from legally subordinating the indebtedness to other relevant debt) and making explicit that it does not entail the obligation to pay bondholders on a ratable basis.

It is evident from the above that each category of creditors requests equal treatment: the debtor State undertakes not to offer better terms to creditors of the same class not taking part in the restructuring. In addition, the debtor State is requested to offer a comparable treatment among classes of creditors.

Nowadays, the comparability of treatment has become one of the cornerstones of the Paris Club $^{17}$ but, in the absence of inter-class binding agreements, it is not easily achievable or enforceable.

NML, case 13-990. Brief of Joseph Stiglitz as amicus curiae in support of petitioner (24 March 2014) filed before the Supreme Court of the United States in the case Republic of Argentina v. NML, case 13990. See also IMF, 'Sovereign Debt Restructuring - Recent Developments and Implications for the Fund's Legal and Policy Framework', 26 April 2013, 30 ff.

${ }^{15}$ See ICMA, "Standard Pari Passu Provision for the Terms and Conditions of Sovereign Notes", August 2014, available at http://www.icmagroup.org/resources/Sovereign-Debt-Information/ (last visited 10 January 2015).

${ }^{16}$ See IMF, 'Strengthening the Contractual Framework to Address Collective Action Problems in Sovereign Debt Restructuring', October 2014, p. 7 ff.

${ }^{17}$ Philip R Wood QC gives an example of a clause: 'In order to secure comparable treatment of its debt due to all its external public or private creditors, the Government of the Republic of [ ] commits itself to seek promptly from all its external creditors debt reorganisation arrangements on terms comparable to those set forth in the present Agreed Minute, while trying to avoid discrimination among 
The debtor undertakes to seek from non-Paris Club creditors a treatment comparable to the one granted in the Agreed Minutes. This is understood to apply to States not represented in the Club, international organizations and private creditors, the only exception being the recognition of preferred creditor status to the IMF, the World Bank and regional development banks. Breaching the comparability principle would entail the cancellation of Paris Club debt relief.

Besides, the Paris Club does not acknowledge the validity of the so-called reverse comparability principle: in fact, public creditors do not feel bound by a haircut agreed by the private sector. ${ }^{18}$ The rationale behind this stance is that, unlike private creditors, public creditors do not lend for profit purposes. Consequently, an effort made by private creditors cannot be a benchmark for the public sector.

Finally, it should be recalled that these non-discrimination principles were never applied before World War II: at the time, commercial, political and diplomatic relations

different categories of creditors. Consequently, the Government of the Republic of [...] commits itself to accord all categories of creditors and in particular creditor countries not participating in the present Agreed Minute, and private sector creditors treatment not more favourable than that accorded to the Participating Creditor Countries for credits of comparable maturity.' (PR Wood, 'How the Greek Debt Reorganisation of 2012 Changed the Rules of Sovereign Insolvency' (2013) 14 (1) Business Law International 41). R. Olivares Caminal puts forward another example explicitly mentioning bondholders: 'In order to secure comparable treatment of its debt due to all its external public or private creditors, the Government of the Islamic Republic of Pakistan commits itself to seek from ... bond holders the reorganization of bonds' (R Olivares-Caminal, Debt Restructuring (2011) 423).

${ }^{18}$ T Lambert, 'Debt Restructuring Experience: the Paris Club' (2011), p. 4, paper presented at the conference 'The missing link in the international financial architecture: sovereign debt restructuring' organized by Ministerio de Economía y Finanzas Argentino, Buenos Aires, 7 December 2011, available at http://www.mecon.gov.ar/finanzas/deuda\%20soberana/lambert.pdf. 
resulted in a cobweb of preferential treatments and elaborate schemes differentiating among creditors and among the currencies in which the debts were to be paid. ${ }^{19}$

The first time the foreign debt of a country was restructured collectively was in 1953 when the Agreement on German External Debts was signed in London. ${ }^{20}$ However, only when the focus shifted on restoring a country's long-term debt sustainability, the equality and comparability of treatment became relevant and translated into standard clauses.

\section{The preferred creditors status of international financial institutions}

Preferred creditor status is only enjoyed by the IMF, the World Bank and multilateral development banks (MDBs): countries borrowing from these international organizations are expected to grant them priority over other public or private creditors.

\footnotetext{
${ }^{19}$ See RA Morales, 'Equality of Treatment of Creditors in the Restructuring of Foreign Debt', in D Carreau, MN Shaw (eds), The External Debt (1995) $381 \mathrm{ff}$.
}

${ }^{20}$ One of the first application of the principle can be found in Art. 8 ('Prohibition of Discriminatory Treatment') of the Agreement on German External Debts, signed in London on 27 February 1953, which provides that: 'The Federal Republic of Germany will not permit, nor will the creditor countries seek from the Federal Republic of Germany, either in the fulfilment of terms of settlement in accordance with the present Agreement and the Annexes thereto or otherwise, any discrimination or preferential treatment among the different categories of debts or as regards the currencies in which debts are to be paid or in any other respect. Differences in the treatment of different categories of debt resulting from the settlement in accordance with the provisions of the present Agreement and the Annexes thereto shall not be considered discrimination or preferential treatment'. On the London Debt Agreement see RM Buxbaum, 'The London Debt Agreement of 1953 and Its Consequences', in HE Rasmussen-Bonne, R Freer, W Lüke, W Weitnauer (eds), Balancing of Interests, Liber Amicorum Peter Hay zum 70. Geburtstag (2005) 55-72. 
In the 1980s, some authors expressed the view that the privileged status of the IMF came from an international customary law norm. ${ }^{21}$ Others, however, contended that a general international law rule to this end had not arisen yet and that "decisions by some creditors [Paris club members] to extend de facto preferential status to IFIs [...] differ fundamentally from a legal right of being exempt, even though the private sector has often acquiesced".22

In the context of the so-called 'protracted arrears crisis' of the late 1980s (1983$1992)^{23}$, the same IMF had to acknowledge the feeble legal grounds for its preferred creditor status and it "urged all members, within the limits of their laws, to treat the Fund as a preferred creditor" (emphasis added). ${ }^{24}$

${ }^{21}$ D Carreau, 'Le rééchelonnement de la dette extérieure des Etats' (1985) 112 Journal du droit international 5, 15.

22 RSJ Martha, 'Preferred Creditor Status under International Law: The Case of the International Monetary Fund' (1990) 39 Int'l and Comp L.Q. 801, at 825.

${ }^{23}$ By 1988, 13 countries were in protracted arrears (of six or more months) with the Fund. Arrears amounted to nearly 14 per cent of the outstanding IMF loans.

24 'IMF Survey', 17 October 1988, p. 326. See also Report of the Executive Board to the Interim Committee of the Board of Governors on Overdue Financial Obligations to the Fund, EBS/88/166, Rev. 2, 9 September 1988, p. 3: "Executive Directors have stressed the unique position of the Fund as an international cooperative institution, its role in the international monetary system, the revolving nature of its resources, and the consequent need for all members, creditors and debtors alike, in practice, to treat the Fund as a preferred creditor. Accordingly, all members should accord the highest priority to the settlement of financial obligations to the Fund". For a comment and the text of this document, see J M Boughton, Silent Revolution: The International Monetary Fund 1979-1989 (2001), Washington, DC, IMF, p. $820-21$ and 832 . 
Not even treaty law is of avail. In fact, in the Articles of Agreement there is no explicit reference to the Fund's preferred creditor status. ${ }^{25}$ Nonetheless, in the practice of the Paris Club and of the G20 countries $^{26}$ the IMF is always awarded priority. It is almost undisputed that, when the Fund provides financial assistance to a member State, its claims are senior to those of all the other creditors.

More recently, some Authors pointed out that: "the IMF plays different roles by wearing different 'hats'. Among these are: (1) that of an 'honest broker' or arbiter between creditors and debtors; (2) a primary lender by means of providing financial assistance to countries experiencing balance of payment needs; (3) a preferred creditor with an interest at stake; (4) an international lender of last resort; (5) a crisis manager; and, (6) a standard setter. Therefore, putting the IMF claims together with commercial

${ }^{25}$ See K Raffer, 'Preferred or Not Preferred: Thoughts on Priority Structures of Creditors' (2009), paper prepared for discussions at the 2nd meeting of the ILA Sovereign Insolvency Study Group, 16 October 2009, available at http://homepage.univie.ac.at/kunibert.raffer/ila-wash.pdf (last visited 10 January 2015), as well as RSJ Martha, 'Preferred Creditor Status under International Law', cit., 813 ff.

${ }^{26}$ At the October 2011 meeting of Cannes, the G20 Finance Ministers and Central Bank Governors endorsed a document entitled Principles for Cooperation between the IMF and Regional Financial Arrangements. This soft law instrument acknowledges the importance of cooperation between the IMF and RFAs to promote regional and global financial and monetary stability. The G20 Principles do not establish a hierarchy between the IMF and the RFAs, if not for the preferred creditor status that is recognized to the IMF. This is also acknowledged by the European Stability Mechanism Treaty (ESM): 'the ESM loans will enjoy preferred creditor status in a similar fashion to those of the IMF, while accepting preferred creditor status of the IMF over the ESM' (Preamble of the ESM Treaty, n. 13). Therefore, under normal practice, the debtor country will first repay the IMF, then the ESM, and last its private creditors (A Mody, 'Sovereign Debt and Its Restructuring Framework in the Euro Area' (2013) Bruegel Working Paper 2013/05, 20-21). 
claims in a workout would fundamentally undermine the Fund's capacity to play those vital roles in future". ${ }^{27}$

It was also argued that, without preferred creditor status, the IMF would greatly limit its lending activities, especially in the case of countries struck by a debt crisis. ${ }^{28}$ In this sense, preferential treatment is considered fundamental to ensure that the IMF's reserve assets remain risk-free. This 'adequate safeguard' (within the meaning of IMF Art. V, Section 3) reflects the global public good nature of the IMF financing, which is intended to restore the recipient country "external viability, thus also ensuring that the other creditors will have their restructured claims repaid". ${ }^{29}$

It should be noted that even in the context of the HIPC initiative, the IMF and the IDA maintained their preferred creditor status. Debt relief was in fact provided in a way to formally guarantee that payments to the IMF/IDA were made as they fell due. In practice, much of the debt relief was disbursed by a special Debt Relief Trust Fund, financed from IBRD income, or by special ESAF grants provided by the IMF. A portion of the HIPC debt was also allocated directly to member States of the IDA as part of

${ }^{27}$ R Olivares-Caminal, ‘The EU Architecture to Avert a Sovereign Debt Crisis' (2011) OECD Journal: Financial Market Trends, Issue 2, 18. See also RM Lastra, Legal Foundations of International Monetary Law (2006) 491-498.

${ }^{28}$ S Schadler, 'The IMF's Preferred Creditor Status: Does It Still Make Sense after the Euro Crisis?', CIGI Policy Brief n. 37, March 2014. The Author concludes: "Ultimately, the case for or against PCS for the IMF comes down to how members wish to maintain discipline over IMF lending. There are two choices: discipline through rules, that is, a clear framework specifying minimum standards for the credibility that IMF programs will return a country to market access, or discipline through market forces, that is, subjecting IMF loans to the same risks of default or restructuring as private market lending”.

${ }^{29}$ IMF, 'Review of Fund Facilities: Analytical Basis for Fund Lending and Reform Options', 6 February 2009, 8 . 
their replenishment contributions. These funds were used to buy back or repay portions of the debt owed by HIPC countries to the IDA and the IMF; in the alternative, the Trust Fund committed to pay a portion of the future debt service owed to multilateral creditors as it fell due. ${ }^{30}$

What seen for the IMF's preferred creditor status applies also to the IBRD, IDA and MDBs. ${ }^{31}$ Their statutes do not contain a legal basis for preferential treatment, nor does general international law. Though, since they provide development financing, they are granted de facto priority.

\section{International financial institutions as bondholders: do they still enjoy preferred creditor status?}

This paragraph is devoted to analyse whether the IMF and the IBRD should be entitled to claim preferred creditor status even when they purchase government bonds for investment purposes.

While the IMF has only recently started to play an active role as an investor, the IBRD has a long history of buying and selling securities on the international capital markets for investment purposes.

${ }^{30}$ See LF Guder, The Administration of Debt Relief by the International Financial Institutions: $A$ Legal Reconstruction of the HIPC Initiative (2009) 49. See also IMF, 'HIPC Initiative and MDRI: Statistical Update', 19 December 2013.

${ }^{31}$ On this point see K Raffer, cit. above, and K Raffer, Debt Management for Development: Protection of the Poor and the Millennium Development Goals (2010), Cheltenham, 221 ff. The Author argues that, on the contrary, the IBRD founders wanted to subordinate the bank's claims. 
The Fifth Amendment to the IMF Articles of Agreement (which entered into force in February 2011) broadened the investment mandate of the Fund. ${ }^{32}$ The purposes of the changes introduced were to ensure the long-term sustainability of the Fund's finances, and to make it less dependent on borrowing from member States and on earnings deriving from its lending activities. ${ }^{33}$

The advocates of a more radical proposal claimed that the Fund should have been granted the power to buy sovereign bonds on secondary markets to provide liquidity to countries in distress, stabilize debt markets and reduce spreads. In this way, the Fund would have acted as a lender of last resort, supporting countries with high debt levels without adding to their overall debt stock. ${ }^{34}$ This proposal, however, was set aside and the Fifth Amendment only introduced a new investment device.

Under the new income model, the Fund is allowed to invest part of its resources in fixed-income securities and short-term deposits to generate returns exceeding the SDR

${ }^{32}$ In particular, the Fifth Amendment modified Art. XII, Section 6(f)(iii) of the Articles of Agreement. See the IMF Executive Board Resolution No. 63-3: 'Proposed Amendment of the Articles of Agreement of the IMF to Expand the Investment Authority of the IMF', 5 May 2008 in IMF, Summary Proceedings of the Sixty-Second Annual Meetings (2008) 209-211. On the IMF new income model see B Steinki and W Bergthaler, 'Recent Reforms of the Finances of the International Monetary Fund: An Overview' in C Herrmann and JP Terhechte (eds), European Yearbook of International Economic Law (2012) 3 EYIEL 635-666; S Hagan, 'Reforming the IMF', in IMF, Current Developments in Monetary and Financial Law: Restoring Financial Stability - The Legal Response (Volume 6) (2012) $253 \mathrm{ff.}$

${ }^{33}$ See IMF Annual Report 2013, Appendix VI, Financial Statements, 30 April 2014, p. 13 and 16, available at http://www.imf.org/external/pubs/ft/ar/2013/eng/pdf/a6.pdf, accessed 10 July 2014.

${ }^{34}$ See in particular: A Lerrick and A Meltzer, 'Blueprint for an International Lender of Last Resort' (2003) 50 (1) Journal of Monetary Economics 289-303. 
interest rate. More specifically, the Fund can purchase "directly in the cash markets" obligations issued by member States and other international financial institutions. ${ }^{35}$

However, the prudent risk profile of the Fund enables it to invest only in: (a) government bonds denominated in currencies included in the SDR basket (or denominated in SDR); (b) bonds issued by international financial organizations; (c) claims on the Bank for International Settlements (BIS); and (d) short-term deposits held at the BIS.

Credit risk is further minimized by restricting investments to financial instruments with a credit rating at least equivalent to A, based on the Standard \& Poor's rating scale. ${ }^{36}$ The consequence is that the Fund's external investment managers ${ }^{37}$ will be compelled to sell financial instruments in their portfolio as soon as these go below the

${ }^{35}$ IMF, 'Rules and Regulations for the Investment Account', as revised by the Executive Board the 23 January 2013, available at http://www.imf.org/external/np/pp/eng/2012/122812.pdf, accessed 20 July 2014. The Investment Account (IA) of the IMF is divided in three different subaccounts (among which the Fixed-Income Subaccount). It holds resources transferred from the General Resources Account (GRA), which are to be invested to broaden the IMF's income base. The earnings generated by the IA may be retained in the IA or transferred to the GRA to help meet the expenses of conducting the business of the IMF.

${ }^{36}$ If the rating threshold is breached, assets shall be divested within three months from the rating downgrade.

${ }^{37}$ The assets in the IMF Investment Account are managed by external operators with a clear separation of responsibilities from the IMF management (the IMF Managing Director and the Executive Board). 
rating threshold. This rigidity is even likely to increase the chances of the organization to bear losses. ${ }^{38}$

The IBRD has a less prudent investor profile. Pursuant to Art. IV, Section 8 (iv) of the Articles of Agreement, the IBRD can buy and sell such other securities as the Directors may deem proper for the investment by a three-fourths majority of the total voting power. ${ }^{39}$ All investment activities are conducted in accordance with the Investment Guidelines, which establish trading and operational rules, eligibility criteria for IBRD's investments, as well as risk parameters relative to benchmarks.

In its Liquid Asset Portfolio, the IBRD holds principally obligations issued or unconditionally guaranteed by a government of a member country, issued by an agency or instrumentality of a member country or by a multilateral organization. ${ }^{40}$ In this case, only obligations rated AA- or more are eligible for IBRD's investment; however, if they are denominated in the currency of the issuing State, no rating is required. Besides, the IBRD can also invest in corporate and asset-backed securities, time deposits and other unconditional obligations of banks and financial institutions and other instruments.

${ }^{38}$ RSJ Martha, 'International Organizations Sovereign Bondholders' cit., p. 3. Besides, the World Bank Treasury currently manages the investment of over USD 100 billion in high-grade fixed-income portfolios in US dollars, Euros, Sterling and Yen for several types of institutions, including other IFIs, donor trust funds and central banks of its member States.

${ }^{39}$ The IBRD is also one of the major borrowers on the financial markets and raises most of its funds from the issuance of bonds (which carry an AAA rating because their repayment is guaranteed by its member States).

${ }^{40}$ See The World Bank Annual Report 2013, IBRD Management's Discussion and Analysis, 30 June 2014, p. 20 and 33, available at http://siteresources.worldbank.org/EXTANNREP2013/Resources/9304887-1377201212378/93058961377544753431/IBRD_FinancialStatements.pdf, accessed 10 July 2014. 
In light of the above, the two Bretton Woods institutions are exposed to the risk of losses, which is well illustrated by the Hypo Alpe Adria case. The IBRD had invested around $€ 150$ million in subordinated debt instruments of the Austrian Hypo Alpe Adria Bank International Group AG. ${ }^{41}$ In 2009, after years of high-risk project financing, mismanagement and corruption, ${ }^{42}$ the Austrian government nationalized the bank to avoid its insolvency. In August 2014, as a result of the entry into force of the Federal Law on the Reorganization of the Hypo Alpe Adria bank $(\mathrm{HaaSanG})^{43}$, all its subordinated debt - previously guaranteed by the State of Carinthia, where the bank had its registered office - was written off. ${ }^{44}$

\footnotetext{
${ }^{41}$ Among affected investors is Aurelius Capital Management LP, the hedge (vulture) fund which challenged the Argentina sovereign debt restructuring in front of US courts.

${ }^{42}$ Several criminal investigations are undergoing. See The Wall Street Journal, 'Untangling the Mess
} of Austrian Bank Hypo’, 28 August 2014.

${ }^{43}$ The Austrian Federal Law on the reorganisation of Hypo Alpe Adria Bank International AG (Bundesgesetz über Sanierungsmaßnahmen für die Hypo Alpe Adria Bank International AG - HaaSanG) was published in the Austrian Federal Legal Gazette Nr. I 51/2014 on 31 July 2014. The HaaSanG has, pursuant to its Section 13, become effective on 1 August 2014. The text of the Austrian Federal Law is available at:

http://www.ris.bka.gv.at/Dokumente/BgblAuth/BGBLA 2014 I 51/BGBLA 2014 I 51.html (last visited 10 January 2015). See also the ECB Opinion of 29 July 2014 on reorganisation and winding-up measures regarding the Hypo Group Alpe Adria (CON/2014/61). Besides, the conformity of the Austrian legislation with Austrian constitutional law and European law has already been challenged by a large number of different parties.

44 The Austrian Financial Market Authority (FMA) was appointed as the competent authority to implement the statutory reorganization and winding-up measures foreseen by the law. With the adoption publication of a FMA regulation on the $7^{\text {th }}$ of August 2014, certain subordinated liabilities and shareholder liabilities of the bank as well as most guarantees and collateral for such liabilities are 
The IMF condemned the $€ 890$ million wipe-out of subordinated debt and urged Austria to reconsider it: "while designed and intended as an isolated case, the prospective wipe-out risks calling into question similar guarantees issued by other subnational bodies". 45

According to the press, discussions were held with the Austrian authorities to exempt the holdings of the IBRD from the scope of the law, but to no avail. Applicable EU law - the Bank Recovery and Resolution directive ${ }^{46}$ - contains no reference to a bail-in exemption for international organizations. The issue therefore can only be solved if the IBRD is recognized as preferred creditor.

Similarly, in the case of a country's default, the issue arises over whether to shield supranational bondholders from a sovereign debt restructuring.

As stated above, when providing financial assistance, the IFIs preferred creditor status has rarely been challenged. The question is whether the same should apply when the IFIs act as mere investors in the capital markets.

extinguished. At the same time, for certain disputed liabilities the due date is deferred until a final court judgment is reached. The affected liabilities are listed in the FMA Regulation; its text is available at: http://www.ris.bka.gv.at/Dokumente/BgblAuth/BGBLA 2014 II 195/BGBLA 2014 II 195.pdf (last visited 10 January 2015).

${ }^{45}$ Source: IMF, Austria - 2014 Article IV Consultation Preliminary Conclusions, 1 July 2014, par. 10.

${ }^{46}$ Directive 2014/59/EU of the European Parliament and of the Council of 15 May 2014 establishing a framework for the recovery and resolution of credit institutions and investment firms, OJ L 173, 12 June 2014, p. 190. 
We advocate that, when buying bonds on secondary markets, the IMF and the IBRD are comparable to private investors, as the speculative nature of the investment activity prevails over their public function. Hence, in the case of a debt restructuring or of a winding up of a company, they should not be treated in a more favourable way, but share an equal burden with any other bondholder.

On the other hand, some argue that, when acting as investors, the IMF/IBRD are still pursuing their global public good objectives, since their investments are aimed at ensuring the proper financing of their activities in the long run. If we agreed to this view, the IMF/IBRD would be granted preferred creditor status and their bonds would be rightfully exempted from a debt restructuring.

This is precisely what happened to the bonds held by the ECB, the Eurosystem NCBs and the EIB in the context of the March 2012 Greek exchange offer, even if none of these supranational institutions has ever been acknowledged preferred creditor status.

As we will see, while the EIB purchased Greek sovereign bonds under its investment mandate, ${ }^{47}$ the ECB's purchases were made in the exercise of its monetary policy mandate and in response to public interest considerations. The rationale for the ECB's exemption seems to lie in the public good objectives it was pursuing.

\footnotetext{
${ }^{47}$ See Art. 21 of the Statute of the European Investment Bank (version dated 1 July 2013): 'The Bank may employ any available funds which it does not immediately require to meet its obligations in the following ways: (a) it may invest on the money markets; (b) it may, subject to the provisions of Article 18(2), buy and sell securities; (c) it may carry out any other financial operation linked with its objectives. $[\ldots]^{\prime}$.
} 


\section{The exemption of the ECB, Eurosystem NCBs and the EIB from the Greek sovereign debt restructuring}

In May 2010, the ECB and NCBs started to make outright purchases of sovereign bonds issued by governments of the Euro area on the secondary market (i.e. from banks and at market prices). These interventions were made under the legal framework of the Securities Markets Programme (SMP), ${ }^{48}$ a monetary policy instrument adopted due to

\footnotetext{
${ }^{48}$ The SMP programme was discontinued in September 2012, when the ECB announced the introduction of the new Outright Monetary Transactions programme (OMT) under which secondary market purchases of public debt instruments will be carried out only if the sovereign concerned agrees to a EFSF/ESM financial reform programme and its attached conditionality. See ECB Decision of 14 May 2010 establishing a securities markets programme (ECB/2010/5), OJ L 124/8, 20.5.2012. See also ECB, 'The ECB's Non-Standard Measures - Impact and Phasing Out' (July 2011) Monthly Bulletin 66; D Zandstra, 'The European Sovereign Debt Crisis and Its Evolving Resolution' (2011) 6 Capital Markets Law Journal 285-316, at 291. On the OMT, see ECB Press Release, 'Technical Features of Outright Monetary Transactions', 6 September 2012, www.ecb.int. The ECB Governing Council has not yet adopted a decision detailing the legal framework for the OMT programme.
}

The SMP/OMT programmes were object of strong criticisms and they were challenged in front of the German Federal Constitutional Court (GFCC). On 14 January 2014, the GFCC separated from the proceedings related to the ESM and to the Treaty on Stability, Coordination and Governance in the Economic and Monetary Union (the so-called Fiscal Compact) the matters related to the SMP and the OMT programmes. The proceedings related to the SMP/OMT were stayed and a referral for a preliminary ruling was submitted by the GFCC (for the first time in its history) to the Court of Justice of the European Union asking the CJEU to assess whether the OMT programme is covered by the monetary policy mandate of the ECB and whether the SMP/OMT programmes are consistent with the prohibition of monetary financing enshrined in Art. 123 TFEU. See German Federal Constitutional Court (Bundesverfassungsgericht), Orders of 17 December 2013 and of 14 January 2014: BVerfG, 2 BvR 1390/12 vom 17.12.2013, http://www.bverfg.de/entscheidungen/rs20131217_2bvr139012.html and 
the exceptional circumstances that were hampering the monetary policy transmission mechanism in the Euro area. ${ }^{49}$

As a result of the SMP purchases, in February 2012 the ECB was the single largest holder of Greek sovereign bonds, with 16.3 per cent of the total, amounting to $€ 42.7$ billion. Notably, purchases were made at a discount: spending about $€ 40$ billion for bonds having a face value of $€ 55$ billion. ${ }^{50}$ The Eurosystem NCBs held around 5 per cent of the total Greek bonds, amounting to $€ 13.5$ billion, while the EIB had invested for just 0.1 per cent of the total, amounting to $€ 315$ million. Their cumulative holdings amounted to more than 20 per cent of the total outstanding bonds. ${ }^{51}$

During the restructuring, these supranational creditors were shielded from bearing any losses: in mid-February 2012, shortly before Greece launched its exchange offer, they swapped their 'old' bonds for 'new' bonds with identical nominal value, payment terms and maturity dates, but different serial numbers. ${ }^{52}$

BVerfG, 2 BvR 2728/13 vom 14.1.2014, Absatz-Nr. (1 - 105),

http://www.bverfg.de/entscheidungen/rs20140114 2bvr272813en.html. See the special issue of the German Law Journal on 'The OMT Decision of the German Federal Constitutional Court', vol. 15, n. 2, 1 March 2014.

${ }^{49}$ See Recital 2 of the ECB Decision of 14 May 2010 establishing a securities markets programme (ECB/2010/5), OJ L 124/8, 20.5.2012.

${ }^{50}$ See IMF, 'Euro Area Policies: 2012 Article IV Consultation - Selected Issues Paper', IMF Country Report No. 12/182, July 2012, p. 47.

${ }^{51}$ J Zettelmeyer, C Trebesch, M Gulati, 'The Greek Debt Restructuring: An Autopsy' (2013) Peterson Institute for International Economics Working Paper, WP 13-8, 10. See also Morgan Stanley, 'Trading After the PSI', 8 March 2012.

52 The new bonds with different ISIN numbers (International Securities Identification Number) were kept outside the remit of the Greek Bondholder Act and therefore were not involved in the application of 
This was the only way to single out and aggregate bonds issued under different series. The new bonds were in fact protected from the debt swap that was carried out under the so-called Private Sector Involvement (PSI) and performed by means of retroactive collective action clauses. ${ }^{53}$

The Greek exchange offer did not extend to bonds held by the ECB, Euro area NCBs and the EIB, but it did extend to retail and institutional bondholders as well as to other non-European sovereign bondholders and central banks. ${ }^{54}$

retroactive CACs. See IMF, 'Euro Area Policies: 2012 Article IV Consultation - Selected Issues Paper’, cit., p. 47.

${ }^{53}$ On 23 February 2012, the Greek Parliament introduced Law 4050/2012 on Rules on the modification of titles issued or guaranteed by the Greek state with the Bondholders' agreement (published in Government Gazette A 36/23.02.2012 of the Hellenic Republic), by which CACs were to be retroactively introduced on all Greek bonds issued before 31 December 2011 (93 per cent of the outstanding sovereign bonds were governed by Greek law).

Around 7.3 per cent of the outstanding Greek debt was governed by foreign law and included CACs. For more than half of these foreign-law bonds, holdouts were able to acquire a blocking majority neutralising the operation of the CACs (normally to secure a blocking position a holdout creditor needs to hold more than 25 per cent of the same bond issuance). They are still being serviced according to the original terms (see J Zettelmeyer, C Trebesch, M Gulati (2013) cit., 13-14).

${ }^{54}$ PR Wood (2013) cit., 34. For instance, the Norwegian Government Pension Fund Global had to suffer a huge loss after having stocked up on Greek debt (and on bonds of Portugal, Spain and Italy) and having started to downsize its portfolio only at the end of 2011 (data available at http://www.nbim.no/en/Investments/, last visited 9 September 2014). Besides, when in March 2012 the IMF approved a $€ 28$ billion arrangement under the Extended Fund Facility for Greece, its preferred creditor status was acknowledged and upheld by the Executive Directors; see IMF (2013), 'Sovereign Debt Restructuring - Recent Developments', cit., p. 35. 
The exemption of supranational bondholders led to the development of a very unusual ladder of priorities among creditors ${ }^{55}$ and it was considered discriminatory in nature. ${ }^{56}$ The result was that the claims of these European official sector institutions were de facto granted seniority, to the detriment of both retail and institutional investors. The Greek sovereign debt restructuring was the first case in which private debt holders were subordinated to supranational bondholders.

While bondholders agreeing to the exchange offer received bonds maturing between 2023 and 2042 and suffered a huge haircut (53.5 per cent on their principal), the maturity dates of the bonds held by the ECB and the other supranational bondholders remained unvaried. The ECB would in fact receive the full face value of the Greek bonds it had purchased at significantly below par value and it would also benefit from coupon payments, ${ }^{57}$ thus receiving de facto preferential creditor status.

\footnotetext{
${ }^{55}$ PR Wood (2013) cit., 32.
}

${ }^{56}$ According to the IIF Joint Committee on Strengthening the Framework for Sovereign Debt Crisis Prevention and Resolution, 'the exclusion of the ECB holdings from the debt exchange could be rationalized [...], but the exclusion of the official body holdings [NCBs and EIB] deviated from the normal principle of non-discrimination' (IIF, 'Report of the Joint Committee on Strengthening the Framework for Sovereign Debt Crisis Prevention and Restructuring', October 2012, p. 15). See also the Addendum to the Principles for Stable Capital Flows and Fair Debt Restructuring (the document is attached to the IIF 2012 Report, cit.), in particular paragraph 5, titled 'Fair and Comparable Treatment of All Creditors'.

${ }^{57}$ It has to be underlined that the ECB earned huge profits from the SMP operations, not only because of the lower cost of ECB funding relative to the interest rate on the bonds, but above all because it bought the bonds at a discount to par (for about $€ 40$ bn versus $€ 55$ billion face value). Data from: IMF, 'Euro Area Policies: 2012 Article IV Consultation - Selected Issues Paper', cit., 47. 
The decision to grant preferential treatment to the ECB resulted in an aggravated sense of grievance on the part of the disfavoured creditors and it was harshly criticized.

On the issue it was observed that: "The larger the share of the privileged creditors becomes (protected against losses in case of a debt cut), the higher the default risks for the underprivileged (private) creditors rise". ${ }^{58}$

Furthermore, the fact that part of the money disbursed to Greece by the IMF and Euro area members was used to repay the ECB provoked a flood of indignant reactions. ${ }^{59}$

Initially, the ECB argued that its exemption from the PSI was "special” and justified on the grounds that it had intervened on the bond markets solely for monetary policy purposes. ${ }^{60}$ In a second moment, however, the ECB declared that in similar situations it would be ready to be pari passu with private lenders. ${ }^{61}$ In addition, it committed to

\footnotetext{
${ }^{58}$ K Schneider, 'Questions and Answers: Karlsruhe's Referral for a Preliminary Ruling to the Court of Justice of the European Union’ (2014) 15 (2) German Law Journal 234.

${ }^{59}$ A first group of bonds held by the ECB matured at the end of August 2012. While struggling with the austerity measures and spending cuts required by the Troika, Greece had to repay $€ 3$ billion. This, however, was only a fraction of the $€ 55$ billion face value Greek bonds held by the ECB and by Eurosystem NCBs.

${ }^{60}$ According to Mario Draghi 'the SMP was a monetary policy instrument. So the purchases of Greek bonds done under that program responded to public interest policy - general policy considerations. And as such, they deserve protection.' (M Draghi, President of the ECB, 'Transcript of the Press Conference', 8 March 2012, available at http://www.ecb.int/press/pressconf/2012/html/is120308.en.html).

${ }^{61}$ This will apply to sovereign bond purchases made via the OMT programme. Under the OMT programme, however, the ECB is 'not only able to buy government bonds, but also to sell them again, and their valuation is based on market prices rather than on final maturity' (Introductory statement by the
} 
return any profits on its Greek bond holdings to its shareholders on the basis of their capital subscription (i.e. both Euro and non-Euro area NCBs, with the latter receiving a smaller percentage). ${ }^{62}$

It is worth summarizing what eventually happened to the so-called SMP profits.

In November 2012, the Euro area member States undertook to transfer on a segregated account established in the Bank of Greece (which has to be used exclusively for debt service payments and to redeem maturing bonds) " $^{63}$ "an amount equivalent to the income on the SMP portfolio accruing to their NCBs". ${ }^{64}$

ECB in the proceedings before the Federal Constitutional Court by Jörg Asmussen, Member of the Executive Board of the ECB, Karlsruhe, 11 June 2013).

${ }^{62}$ J Zettelmeyer, C Trebesch, M Gulati (2013) cit., 10.

${ }^{63}$ The Memorandum of Understanding on Specific Economic Policy Conditionality (par. 2.5.6.1) required Greece to adopt measures to safeguard debt servicing and monitor cash flows, avoid diversion of official financing and secure a timely debt servicing (for the text of the Memorandum of Understanding on Specific Economic Policy Conditionality, see European Commission, 'The Second Economic Adjustment Programme for Greece: First Review - December 2012', Occasional Papers 123, December 2012, p. 189 ff.). To these ends, Law 4063/2012 (GG A' 71) established a 'segregated account' in the Bank of Greece. Transfers to the segregated account were made conditional on the implementation by Greece of austerity measures and other reforms. By law, disbursements to this account are not to be used for purposes other than debt servicing. The Greek government also adopted legislation giving priority to debt service vis-à-vis other cash outflows. Moreover, all payments from the segregated account will be subject to 'prior detailed reporting to the EFSF/ESM and ex-post confirmation by the account holder' (IMF, 'Greece: First and Second Reviews under the Extended Arrangement under the Extended Fund Facility’, IMF Country Report No. 13/20, January 2013, p. 183).

${ }^{64}$ Eurogroup Statement on Greece, 27 November 2012, available at http://www.eurozone.europa.eu/media/367646/eurogroup statement greece 27 november 2012.pdf, accessed 10 January 2015 . 
The ECB underlined that return by national governments of resources "analogous" to the SMP profits will be made "at their own discretion and without any implication for the pay-out of profits from NCBs". ${ }^{65}$

In July 2013, the Eurogroup approved a disbursement of $€ 2$ billion to Greece's segregated account. ${ }^{66}$ A first sub-tranche of $€ 1.5$ billion was transferred by the European Stability Mechanism (ESM) ${ }^{67}$ on 31 July 2013 and a second sub-tranche of $€ 0.5$ billion was paid on 17 December 2013 . $^{68}$

Transfers under this scheme were made conditional "upon a strong implementation by the country of the agreed reform measures in the programme period as well as in the post-programme surveillance period". ${ }^{69}$

${ }^{65}$ ECB, Monthly Bulletin, December 2012, p. 44.

${ }^{66}$ Eurogroup, 'Statement on Greece', 8 July 2013, available at http://www.eurozone.europa.eu/media/442728/20130708-EG-Draft-statement-on-Greece-final.pdf, accessed 10 January 2015. Euroarea Member States receiving financial assistance by the EFSF/ESM were not required to participate in the scheme.

See also European Commission, 'The Second Economic Adjustment Programme for Greece - Third Review, July 2013, Directorate-General for Economic and Financial Affairs, Occasional Papers 159, July 2013 par. 103, available at http://ec.europa.eu/economy finance/publications/occasional paper/2013/pdf/ocp159 en.pdf, accessed 10 January 2015.

${ }^{67}$ The ESM was established in 2012 by Euro area Member States to provide financial assistance to members experiencing or threatened by financing difficulties. Latvia adopted the Euro on 1 January 2014 and joined the ESM on 13 March 2014.

${ }^{68}$ See EFSF Press Release, 'EFSF disburses $€ 2.5$ billion to Greece’, 31 July 2013 and EFSF Press Release, 'EFSF Board of Directors approves $€ 500$ million disbursement to Greece', 17 December 2013, available at http://www.efsf.europa.eu.

${ }^{69}$ Eurogroup, 'Statement on Greece', 27 November 2012, cit. 
While the Troika describes the remittance of SMP profits as "additional financing sources" ${ }^{\prime 70}$, these transfers are more similar to conditional aid or donor contributions, than to financial assistance. Conditions are attached to their disbursements, but these are sums that do not need to be repaid and, indeed, they will never be reimbursed. ${ }^{71}$

Besides, disbursement by the $\mathrm{ESM}^{72}$ will provide a shield against claims of breaches of TFEU Artt. 123 and $125 .^{73}$

${ }^{70}$ See European Commission, 'The Second Economic Adjustment Programme for Greece: Third Review', cit., 49.

${ }^{71}$ This leads to another crucial question: was the ESM given the mandate to act as a donor and grant member States in difficulty some sort of 'official aid' or rather is the ESM only competent to provide financial assistance to Euro area member States if indispensable to safeguard the stability of the Euro area as a whole and subject to strict conditionality?

${ }^{72}$ Contribution to the ESM is made by participating member States on the basis of the key for subscription by their national central banks to the ECB's capital. See Art. 11 of the ESM Treaty and its Annex 1 (cfr. Art. 29 of Protocol No. 4 on the Statute of the European System of Central Banks and of the European Central Bank (the ESCB Statute) annexed to the TEU and to the TFEU).

${ }^{73}$ In fact, in the Pringle case (CJEU, Pringle v. Government of Ireland, Ireland and the Attorney General, Case C-370/12, Judgment of 27 November 2012), the CJEU explicitly affirmed that: 'Art. 123 is addressed specifically to the ECB and the central banks of the Member States. The grant of financial assistance by one Member State or by a group of Member States to another Member State is therefore not covered by that prohibition. [...] even if the Member States are acting via the ESM, the Member States are not derogating from the prohibition laid down in Art. $123 \mathrm{TFEU}$, since that article is not addressed to them' (para. 125-126).

Moreover, for what concerns the so-called no bail out clause of Art. 125 TFEU, the CJEU affirmed that the granting of financial assistance by the ESM in no way implies that the ESM will assume the debts of the recipient State, which remains responsible to its creditors for its financial commitments (CJEU Pringle case, cit., para. 138-139). The only requirements for the ESM assistance to be legitimate under 
According to the European Commission, in the period 2012-2020, Greece will receive from Euro area NCBs a total of about €9.3 billion stemming from their SMP profits accruing over time. ${ }^{74}$ In the IMF's estimates, “subject to approval by member country parliaments", the remittance of $€ 9.3$ billion will help Greece in reducing its debt by 4.6 per cent of GDP by $2020 .^{75}$

These likely positive outcomes, however, are only the unintended consequences of the de facto seniority granted to the ECB over private investors.

In fact, the ECB, NCBs and EIB's exemption from the PSI changed the ladder of priorities among bondholders: priority was given to the debt held by some public sector entities - the supranationals - over private bondholders (among which also some sovereign wealth funds). This added complexity in an already complex framework where creditors of a sovereign are usually not paid according to a clear hierarchy.

In conclusion, the following can be observed. The fact that the purchases of Greek sovereign bonds were made by the ECB in the exercise of its monetary policy mandate and responding to public interest considerations might justify the unexpected priority it enjoyed. The same reasoning, though, is not applicable to the EIB, which bought the bonds for sheer investment purposes.

EU law is to be indispensable for the safeguarding of the financial stability of the Euro area as a whole and subject to strict conditions (CJEU Pringle case, cit., para. 136).

${ }^{74}$ Source: European Commission, 'The Second Economic Adjustment Programme for Greece, Third Review - July 2013', Occasional Papers 159, July 2013, p. 214 (Schedule A: Indicative Amounts to be Transferred to the Greek Government by Eurosystem National Central Banks).

${ }^{75}$ Source: IMF, 'Greece: First and Second Reviews under the Extended Arrangement under the Extended Fund Facility', 21 December 2012, 84 (Box 4: Measures taken to address the Greek debt burden). 


\section{The applicability of the pari passu clause to supranational bondholders}

For the purposes of our research, it is interesting to discuss whether, for the operation of the pari passu clause, supranational bondholders should be assimilated to private investors.

Does the pari passu clause prevent a debtor State from treating supranationals differently from the other bondholders?

As explained earlier, supranational bondholders are halfway between private investors pursuing pure economic interests and multilaterals pursuing their public sector objectives.

Therefore, it is not easy to establish whether the argumentation used by the US Second Circuit Court of Appeal in the injunction order of 26 October 2012 in the case NML Capital, Ltd. v. Republic of Argentina is also applicable to payments made to supranational bondholders.

In NML II, the Court affirmed that the case presented no claim that payments to the IMF would violate the contract. Moreover, it held that "A court addressing such a claim in the future will have to decide whether to entertain it or whether to agree with the appellees that subordination of 'obligations to commercial unsecured creditors beneath obligations to multilateral institutions like the IMF would not violate the Equal Treatment Provision [the pari passu clause] for the simple reason that commercial creditors never were nor could be on equal footing with the multilateral organizations". 76

\footnotetext{
${ }^{76}$ US Court of Appeals, Second Circuit affirmed the amended order: NML Capital Ltd. v. Republic of Argentina, 727 F.3d 230 (2d Cir. 2013), 23 August 2013. See also US Court of Appeals, Second Circuit:
} 
For what concerns the IMF lending, it can be inferred from the US Court's reasoning that financial assistance provided by the Fund is inherently different from a debt obligation undertaken by a State by issuing government bonds. Therefore, the reimbursement of IMF loans will not activate the pari passu clause. $^{77}$

May a similar reasoning apply in the case the IMF, or the IBRD, are paid interest coupons on sovereign bonds in their investment portfolio or are reimbursed the principal at maturity?

For instance, before the PSI, the 'old' Greek bonds did not contain a pari passu clause ${ }^{78}$ but, had they contained one, what would have the consequences of granting seniority to the ECB have been? By awarding ECB, NCBs and the EIB (to which interest coupons are paid and the face value of the principal is preserved) a better treatment, would Greece be breaching the pari passu clause?

The ECB provided its support to Greece not by directly lending funds, but by purchasing government bonds also in the view of stabilizing markets and spread. Although the ECB's public good purposes, it is uncertain whether the full repayment of the bonds held by the ECB would have triggered the pari passu or not.

NML Capital, Ltd. v. Republic of Argentina, 699 F.3d 246 (2d Cir. 2012) [2012 BL 283459] Docket 12105(L), 26 October 2012.

${ }^{77}$ On this issue see also RSJ Martha, 'International Organizations Sovereign Bondholders: An Unexplored Dimension of the Sovereign Debt Crisis' (2013) 10 Manchester Journal of International Economic Law 2.

${ }^{78}$ The 'new' Greek rescheduled bonds, issued under English law after the PSI, includes standard creditor protection clauses such as the pari passu and the negative pledge. Greek-law sovereign bonds issued before the restructuring did not contain similar provisions (see PR Wood (2013) cit., 39). 


\section{Collective action clauses and supranational bondholders}

It is worth considering now whether supranational bondholders should be allowed to participate in voting under collective action clauses (CACs) regardless of their creditor status.

CACs are contractual provisions allowing a supermajority of bondholders to modify the features of a specific bond issue, including its payment terms, making the amendments binding also for dissenting minorities.

Under CACs of the first generation, bondholders were entitled to vote only issue by issue; one of the limitations of this solution was that sizeable bondholders were able to buy a blocking majority in a specific bond issue and force the debtor to full repayment (the so-called holdout problem). The new generation of CACs, instead, includes an aggregation clause by which different bond issues may be aggregated for voting and amendment purposes, thus enabling an across-series restructuring.

In both cases, CACs are based on the presumption that all bondholders are to be treated equally and that, in principle, no distinction should be made among the various categories of investors.

Only bonds owned or controlled by the issuer or by any of its public sector instrumentalities are given a different treatment. In fact, some market players have expressed concerns that a sovereign could take advantage of majority amendment clauses, by buying back - either directly or through entities under its control - a sufficient amount of a bond issue to vote for a more favourable restructuring, to the detriment of the other bondholders.

To prevent this scenario, a so-called 'disenfranchisement provision' is included in sovereign bond contracts to protect ordinary creditors, in particular retail investors, from 
a manipulation of votes. ${ }^{79}$ Pursuant to this clause, bonds directly or indirectly in the hands of the issuer are deemed to be non-outstanding and may not be used to vote amendments or considered for the quorum.

A disenfranchisement provision is included both in the EU CAC Model ${ }^{80}$ and in the recently amended ICMA Standard Aggregated CACs. ${ }^{81}$

The question is whether supranational bondholders should be disenfranchised. The public policy objectives they presumably pursue - in conformity with their treaty or statute obligations - differ from those of either the debtor State or private bondholders. Provided that bondholders are not directed by the issuer's will, their motivations are irrelevant and therefore also supranational bondholders should be enfranchised. ${ }^{82}$

${ }^{79}$ See K Drake, "Disenfranchisement in Sovereign Bonds” (2012) Duke Law Working Paper, available at http://papers.ssrn.com/sol3/papers.cfm?abstract id=2007294.

${ }^{80}$ In 2011, the EFC Sub-Committee on EU Sovereign Debt Markets started working on a standardized CAC to be included in new sovereign debt instruments issued by EU member States. See EFC, 'CACs Common Terms of Reference', 17 February 2012, europa.eu/efc/sub_committee/pdf/cac__text_model_cac.pdf, as well as EFC, Supplemental Provisions, 17 February 2012, europa.eu/efc/sub_committee/pdf/cac_-_supplemental_provisions.pdf (last visited 10 January 2015). According to the Treaty establishing the European Stability Mechanism (Art. 12.3), all new euro area government securities with maturity above one year and issued after January 2013 should include a CAC.

${ }^{81}$ See ICMA, "Standard Aggregated Collective Action Clauses (CACs) for the Terms and Conditions of Sovereign Notes", lett. (i) Notes controlled by the Issuer, August 2014, available at http://www.icmagroup.org/resources/Sovereign-Debt-Information/ (last visited 10 January 2015). See also IMF (2014) 'Strengthening the Contractual Framework', cit., p. 26 ff.

${ }^{82}$ C Hofmann, 'Sovereign Debt Restructuring in Europe Under the New Model Collective Action Clauses’ (2014) 49 Texas International Law Journal 407. 
While developing a EU CAC Model, the view was expressed that "neither an investor's interests or motives, nor the predictability of an investor's vote for or against a proposed modification, constitutes adequate grounds for disenfranchising an investor. $[\ldots]$ the litmus test remains: is a bondholder acting in its own interest? If so, the bondholder should be enfranchised $[\ldots]^{\prime}{ }^{83}$

The final EU CAC Model - unlike the ICMA model clause - grants voting power to bondholders with autonomy of decision from the issuer and, in particular, to those which are prohibited from taking, directly or indirectly, instructions from the issuer on how to vote on a proposed modification. ${ }^{84}$

It should be underlined that this provision was discussed when the SMP programme was in force and contains an implicit reference to the ECB and the Eurosystem NCBs. Since their independence is protected by the EU Treaties ${ }^{85}$, their disenfranchisement is not necessary.

As for the IMF and IBRD, their willingness to preserve their preferred creditor status might direct them to vote against any proposed restructuring of the bonds they hold. Even in this case, however, they will retain complete autonomy of decision from the issuer and therefore, according to the actual Euro CACs rationale, they will be enfranchised.

${ }^{83}$ See EFC Sub-Committee on EU Sovereign Debt Markets, "Model Collective Action Clause Supplemental Explanatory Note”, 26 March 2012, available at http://europa.eu/efc/sub committee/pdf/supplemental explanatory note on the model cac 26 march 2012.pdf, p. 6 (last visited 10 January 2015).

${ }^{84}$ Section 2.7 , lett. c, iii), (x) of the European Model CAC.

${ }^{85}$ See Article 130 TFEU and Article 7 of the ECB Statute. They do not enjoy preferred creditor status. 